Article

\title{
Evaluation of the Methane Production Potential of Catfish Processing Wastewater Using Various Anaerobic Digestion Strategies
}

\author{
Mark E. Zappi 1,2, Dhan Lord Fortela 1,2, Wayne Sharp 2,3, Rakesh Bajpai 1,2, Daniel Gang 2,3, \\ William Holmes ${ }^{1,2}$, Rafael Hernandez ${ }^{1,2}$ and Emmanuel D. Revellame 2,4,*(D) \\ 1 Department of Chemical Engineering, University of Louisiana at Lafayette, Lafayette, LA 70504, USA; \\ zappi@louisiana.edu (M.E.Z.); dhanlord.fortela@louisiana.edu (D.L.F.); bajpair@gmail.com (R.B.); \\ bill@louisiana.edu or bill.holmes@louisiana.edu (W.H.); rhernandez@louisiana.edu or \\ rah7653@louisiana.edu (R.H.) \\ 2 The Energy Institute of Louisiana, University of Louisiana at Lafayette, Lafayette, LA 70504, USA; \\ wsharp@louisiana.edu (W.S.); ddg7603@louisiana.edu (D.G.) \\ 3 Department of Civil Engineering, University of Louisiana at Lafayette, Lafayette, LA 70504, USA \\ 4 Department of Industrial Technology, University of Louisiana at Lafayette, Lafayette, LA 70504, USA \\ * Correspondence: erevellame@louisiana.edu or exr7867@louisiana.edu; Tel.: +1-337-482-6983
}

Received: 11 May 2019; Accepted: 10 June 2019; Published: 12 June 2019

\begin{abstract}
The U.S. catfish industry is a major industry that has been declining over the years due to imports competition and growing operational costs. Catfish processing wastewater management and high energy requirement put a large financial burden on catfish processing facilities. Recovered protein-based solids have provided some value-added co-products, however, more co-products are needed to offset processing costs. Anaerobic digestion is a proven waste treatment method that produces methane, which is an energetic co-product that can be used within the processing facilities. This study was conducted to evaluate the potential of anaerobic digestion as an alternative to the currently used aerobic biotreatment of catfish processing wastewater. Initial assessments indicated the recalcitrance of the full-strength wastewater to anaerobic digestion, yielding only $\sim 4 \mathrm{~m}^{3}$ per ton (U.S.) of input chemical oxygen demand ( $\left.\mathrm{COD}_{\text {input }}\right)$. Thus, several strategies were evaluated to improve the methane yield from the wastewater. These strategies include nutrient (nitrogen and sulfur) amendment, along with ozone, $\mathrm{HCl}$, and $\mathrm{NaOH}$ pretreatment. The results showed that nutrient amendment was the most suitable strategy for improving the digestibility of the catfish processing wastewater. A methane yield of $121-236 \mathrm{~m}^{3} /$ ton (U.S.) $\mathrm{COD}_{\text {input }}$ was obtained, with a purity of $67-80$ vol.\%. These results are similar to yields and purities of biogas from other feedstock, such as food waste, wastewater solids, and fish canning wastewater. This indicates that anaerobic digestion could be a viable alternative for simultaneous treatment and energetic co-product generation from catfish processing wastewater.
\end{abstract}

Keywords: biogas; nutrient amendment; ozonation; $\mathrm{HCl}$ pretreatment; $\mathrm{NaOH}$ pretreatment

\section{Introduction}

Catfish is a major seafood industry in the U.S. that produces over 300 million pounds of fish per year, with the majority of this production found in the Southeast U.S. [1]. U.S. farm-raised catfish ranks eighth on the top ten most eaten fish among U.S. consumers [2], with a consumption of 0.56 pounds per capita each year. This valuable U.S. industry (\$358 million producer sales income in 2013) has decreased 50\% in tonnage produced since its high of over 600 million pounds in 2003 [1,2]. Various factors have contributed to this decline, including the high cost of waste treatment and energy at 
processing facilities, which is not a unique cost issue to just U.S. processors [3]. Yet, the global demand for seafood is expected to increase by $70 \%$, with seafood farming and associated processing viewed as the primary method to meet this demand [4].

During the processing (cleaning and filleting) of the harvested catfish, approximately $40 \%$ of the fish weight is wasted [5,6]. The bulk of this solid waste includes heads, guts, bones, and skin [6]. A significant amount of research has been performed to evaluate potential commercial uses of fish processing waste, mainly solids, into value-added co-products, such as bait, feed protein, and lipids $[7,8]$. Depending on the extent of solids removal, wastewaters generated from catfish processing facilities can differ dramatically with respect to pollutant level. For processors utilizing a large part of the solids for co-product generation, the wastewater can be relatively low in pollutant levels present. Conversely, if a minimal usage of solids is performed, the solids addition can result in a higher strength wastewater. Various water treatment technologies have been used for treating fish processing wastewaters, including air flotation, filtration, aerobic biotreatment, anaerobic digestion, treatment ponds, wetlands, electrocoagulation, and chemical oxidation [9-11].

Anaerobic digestion is a technology in which a consortium of anaerobic microorganisms stepwise degrades the organic waste constituents (typically proteins, lipids, and carbohydrates) into the targeted mineralization products of methane and carbon dioxide (biogas). The energetic value of a biogas is determined by its methane content, with most biogases produced from industrial or agricultural-based digestion systems in the 60-80 vol.\% (methane content) range [12-14]. In most cases, conversion numbers are generally in the $113-453 \mathrm{~m}^{3} /$ ton (U.S.) $\left(2-8 \mathrm{ft}^{3} / \mathrm{lb}_{\mathrm{m}}\right)$ range of chemical oxygen demand (COD) $[15,16]$. Historically, full-scale digestion application efforts have produced very mixed results, with significant financial and technical problems having been noted, often due to poor design and/or difficult site operations $[17,18]$. The produced methane can be fed into a genset for on-site production of electrical power and/or used to replace/displace natural gas as a fuel burned on-site (e.g., an energy source for cookers within a food processor). In the case of power production, the generated power can be used to offset internal electricity usage and/or be inputted into the electrical grid [19]. Ronde et al. [20] reviewed energy costs within a variety of fish processing operations and concluded that an average power usage at these facilities was $1380 \mathrm{~kW}-\mathrm{h}$ per ton (U.S.) of fillets. At $\$ 0.11 \mathrm{~kW}-\mathrm{h}$ power costs, this represents utility costs of over $\$ 150 /$ ton (U.S.) of fillets, or about $\$ 0.17 / \mathrm{kg}$. Therefore, any reduction of costs, such as on-site power generation or replacement of natural gas use, could result in a reduction of production costs for this struggling industry.

The use of digestion for treating fish processing wastewaters has been evaluated using a wide variety of treatment strategies [21,22]. Unfortunately, comparatively little of this research has been focused on the catfish industry. Mendez et al. [23] evaluated both mesophilic $\left(37^{\circ} \mathrm{C}\right)$ and thermophilic $\left(55^{\circ} \mathrm{C}\right)$ digestion for the treatment of fish canning wastewaters. Influent COD concentrations in the 10 to $50 \mathrm{~g} / \mathrm{L}$ range were reduced by as much as 70\%. Gumisiriza et al. [24] evaluated the digestion of wastewaters from Nile perch processing and concluded that the high lipid and ammonia toxicity inhibited digestion of the straight wastewater. However, co-digestion with brewery wastes and utilization of better-acclaimed microorganisms improved methane yield. Palenzuela-Rollon et al. [25] evaluated treating a simulated saltwater fish processing wastewater using an upflow anaerobic sludge blanket reactor. They found that the anaerobic digester removed over $90 \%$ of the COD and yielded a biogas containing over $61 \mathrm{vol} . \%$ methane.

This study was conducted to evaluate the potential of a catfish processing wastewater stream as feedstock for biogas production through anaerobic digestion. The source of the wastewater was an industrial processor who is currently using a three-stage aerated lagoon system (aerobic biotreatment) to treat their wastewater (see Figure 1). Unfortunately, this aerobic treatment system does not offer any co-products for the facility operators to increase plant profitability. Anaerobic digestion is being considered as an alternative option for wastewater treatment, which will also produce energetic co-products for utilization within the processing facility. The objective was to assess different strategies with respect to methane production potential as well as COD reduction effectiveness. 


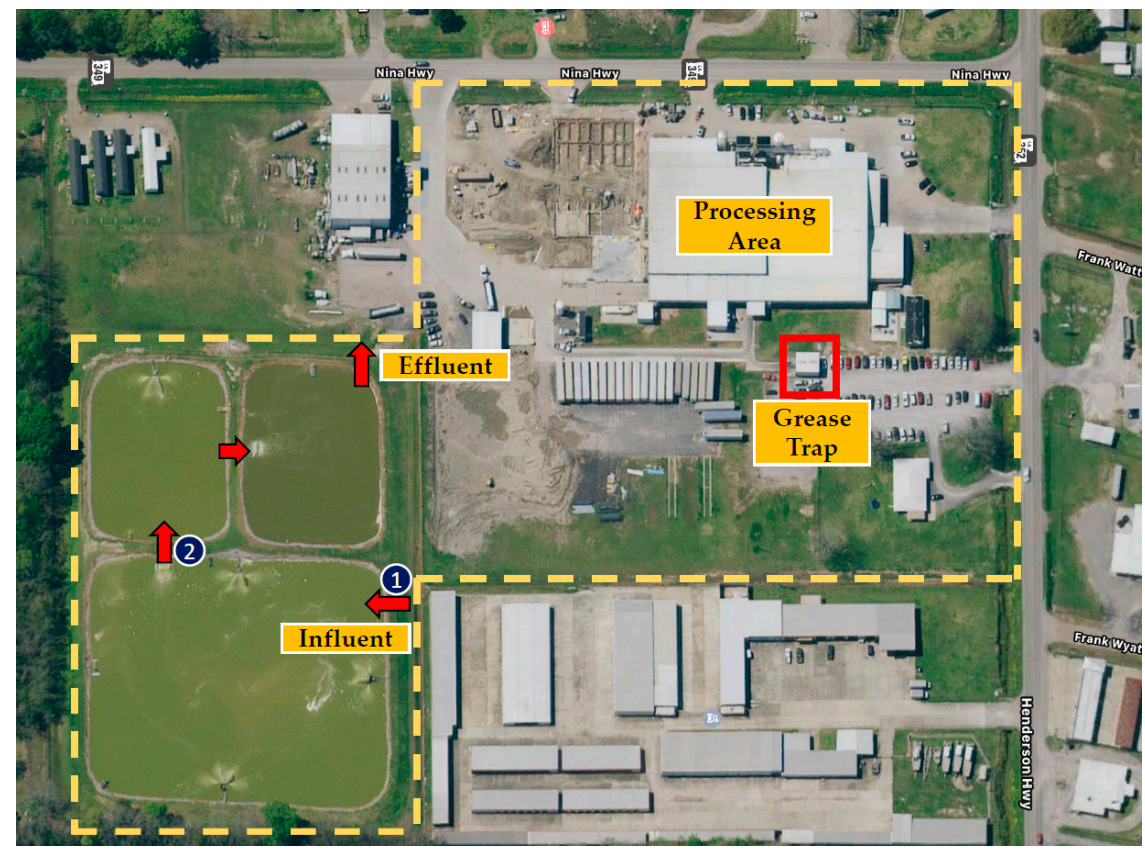

Figure 1. The catfish processing facility where the wastewater used in this study was obtained. Samples were collected from two different locations, annotated by numbers: (1) the influent to the facility's three-stage aerated lagoon biotreatment (full-strength wastewater); (2) influent to the second stage aerated lagoon (partially-treated wastewater).

\section{Materials and Methods}

\subsection{Catfish Processing Wastewater and Seed Sludge}

The catfish processing wastewater was collected from a commercial processor located in Henderson, LA. Two wastewater samples were initially characterized and tested for biochemical methane production potential. The sampling locations for the two samples are indicated in Figure 1. For both sampling locations, the water samples were collected in 1-gallon plastic jugs, transported to the laboratory in ice chests and stored in a refrigerator $\left(4^{\circ} \mathrm{C}\right)$ until needed for testing. Prior to use in a test run, the wastewater samples were allowed to reach room temperature. The microbial seed used in the experiment was thickened sludge $(9 \mathrm{~g} / \mathrm{L}$ total solids), which was collected from a high-performing, large-scale anaerobic digester located at the Lafayette, LA wastewater treatment plant. The digester sludge was collected in 1-L plastic containers and were used in the experiments within an hour after collection, without any pretreatment.

\subsection{Experimental Procedure}

The methane production potential of the two samples was evaluated using 500-mL microcosms designed for the performance of batch anaerobic digestion screening tests (see Figure 2). Unless noted, every data point presented in this paper is an average of duplicate microcosm runs. All of the conditions tested in the microcosm runs involved the following: $\mathrm{pH}$ adjustment to $7.0 \pm 0.2$ using $\mathrm{HCl}$ or $\mathrm{NaOH}$; microbial seed ( 5 vol.\%) addition; and total liquid volume (including the 5 vol.\% of microbial seed) $=250 \mathrm{~mL}$. All microcosms were purged with $\mathrm{N}_{2}$ gas prior to sealing to remove air from the headspace and then the microcosms were placed into the incubator $\left(\mathrm{t}=0\right.$ days) set at $\mathrm{T}=35^{\circ} \mathrm{C}$. No mixing was applied to the microcosms, except during sampling, when the microcosms were gently hand-swirled prior to sample collection. Biogas production was monitored via observation of pressure increases, using a test pressure gauge inserted/sealed into one port of the microcosm. Gas production volumes were estimated using the pressure readings and assuming ideal gas behavior at $\mathrm{T}=25^{\circ} \mathrm{C}$. The headspace gas within the microcosms was periodically sampled using a gas-tight syringe inserted 
into the center of the headspace after microcosm swirling. Collected gas samples were immediately analyzed using a gas chromatograph, as detailed in Section 2.5.2.

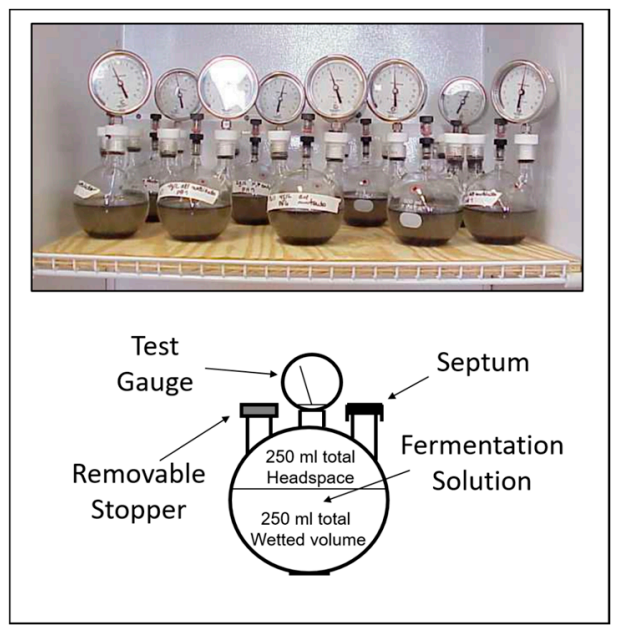

Figure 2. Schematic diagram and photograph of the 500-mL microcosms equipped with pressure gauge and septum-fitted gas sampling port.

\subsection{Digestion Strategies}

The catfish processing wastewater collected from the two sampling locations was initially assessed for methane production potential without any pretreatment or amendments. Based on the results (please see Section 3.1), different operational strategies were applied to the wastewater collected from sampling location 1 , with the aim of improving the methane yield of the full-strength wastewater stream. These strategies included: (1) nutrient amendment; (2) ozone pretreatment (using an Ozonology, oxygen-fed generator with turn-down capacity and oxygen used as the parent gas) + nutrient amendment; (3) $\mathrm{HCl}$ pretreatment + nutrient amendment; and (4) $\mathrm{NaOH}$ pretreatment + nutrient amendment. The details for each strategy are provided in Table 1.

Table 1. Strategies to improve biogas yield from digestion of catfish processing wastewater.

\begin{tabular}{|c|c|c|}
\hline Strategy & Amendment & Pretreatment \\
\hline Control & None & $\mathrm{pH}$ adjustment to 7.0 \\
\hline Nutrient amendment & $\begin{array}{c}\text { Nutrients }\left(\mathrm{NH}_{4} \mathrm{Cl} \text { and } \mathrm{Na}_{2} \mathrm{SO}_{4}\right) \\
\text { were added to adjust the COD:N } \\
\text { to a value of } 40 \text { and S } \\
\text { concentration to } 0.5 \mathrm{mg} / \mathrm{L}^{1}\end{array}$ & Addition of nutrients followed by $\mathrm{pH}$ adjustment to 7.0 \\
\hline $\begin{array}{l}\text { Ozone pretreatment }+ \\
\text { nutrient amendment }\end{array}$ & Similar to nutrient amendment & $\begin{array}{l}\text { Ozone dosage of } 10 \mathrm{mg} \mathrm{O}_{3} / \mathrm{L} \text { wastewater, followed by } \\
\text { addition of nutrients, then pH adjustment to } 7.0\end{array}$ \\
\hline $\begin{array}{l}\mathrm{HCl} \text { pretreatment }+ \text { nutrient } \\
\text { amendment }\end{array}$ & Similar to nutrient amendment & $\begin{array}{l}\text { Acidification with } 5 \mathrm{~N} \mathrm{HCl} \text { to } \mathrm{pH} \sim 2.0 \text { for } 24 \mathrm{~h} \text { (with } \\
\text { stirring) at room temperature, followed by addition of } \\
\text { nutrients, then } \mathrm{pH} \text { adjustment to } 7.0\end{array}$ \\
\hline $\begin{array}{l}\mathrm{NaOH} \text { pretreatment }+ \\
\text { nutrient amendment }\end{array}$ & Similar to nutrient amendment & $\begin{array}{l}\text { Alkali treatment using } 5 \mathrm{~N} \mathrm{NaOH} \text { at } \mathrm{pH} 12 \text { for } 24 \mathrm{~h} \\
\text { (with stirring) at room temperature, followed by } \\
\text { addition of nutrients, then } \mathrm{pH} \text { adjustment to } 7.0\end{array}$ \\
\hline
\end{tabular}

\subsection{Semi-Batch Digestion Runs}

The strategy (please see Section 3.4) that resulted in the highest methane yield was applied to semi-batch digestion experiments using 15-L BioFlo 2000 fermenters (Figure 3). This was done to refine system performance for biogas production using a set-up that mimics an anaerobic digester, including continuous mixing. During the digestion, instantaneous release of biogas from the set-up 
was allowed. The amount of biogas produced was monitored using an online flow totalizer system (DFM 502, Challenge Technology). For these digestion runs, the test influent and amendments were both batch added in the beginning of the experiments. The fermenter also allowed for continuous mixing (100 rpm), along with the provision of sampling of larger water samples $(50 \mathrm{~mL})$ during incubation for periodic analyses without hydraulically impacting system integrity. All 15-L bioreactor runs were performed in duplicate fermenter units operated under the same test conditions and used 5 vol.\% microbial seeding. The units were monitored over time for $\mathrm{pH}$, biogas composition, volume of biogas produced, and short chain carboxylic acids production.

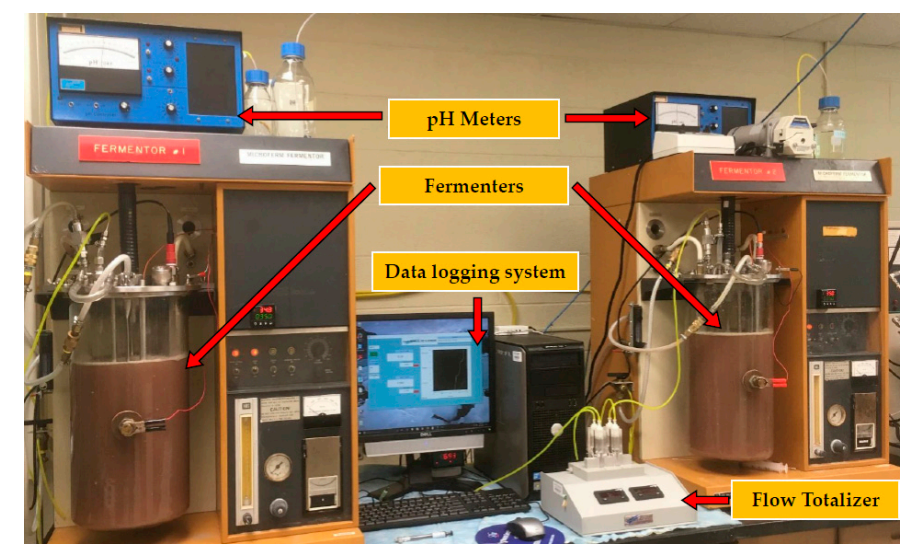

Figure 3. The BioFlo 2000 fermenters used for the semi-batch digestion runs equipped with a data logging system for monitoring $\mathrm{pH}$ and biogas flowrate.

\subsection{Analytical Methods}

\subsubsection{Analyses of Wastewater and Liquid Samples}

COD was analyzed via a Hach DR-3900 and digestion block using Hach TNTplus ${ }^{\text {TM }}$ COD vials (TNT 825) (Hach, Loveland, CO, USA). The $\mathrm{pH}$ values were measured using a Fisher $\mathrm{pH}$ meter and probe (Fisher Scientific, Pittsburgh, PA, USA) that was calibrated using a two-point calibration. Ion chromatography (IC) was used to characterize the wastewaters in terms of the different $\mathrm{N}, \mathrm{P}, \mathrm{S}, \mathrm{Na}, \mathrm{Ca}$, $\mathrm{K}, \mathrm{Mg}$, and Fe species. The IC procedure involved using two Dionex DX600 units both equipped with electrochemical detector (ECD) (Thermo Scientific, Grand Island, NY, USA). One unit was dedicated to anion analysis while the other unit was for cation analysis. Anion analysis utilized a $2 \mathrm{~mm}$ ASRS suppressor and a $\mathrm{KOH}$ eluent generator. The ECD was set at $35^{\circ} \mathrm{C}$ with a $2 \times 250 \mathrm{~mm}$ AS $16(+2 \times$ $50 \mathrm{~mm}$ AG16) at a constant eluent flow of $0.30 \mathrm{~mL} / \mathrm{min}$. The gradient elution was set as follows: $23 \mathrm{mM}$ $\mathrm{KOH}$ for $6 \mathrm{~min}$, ramp to $50 \mathrm{mM}$ at $9 \mathrm{~min}$, and go back down to $23 \mathrm{mM}$ at $12 \mathrm{~min}$, followed by a 4-min stabilization period. The cation analysis used a $2 \mathrm{~mm}$ CSRS suppressor, a methanesulfonic acid (MSA) eluent generator, and a column oven. The oven was set at $30^{\circ} \mathrm{C}$, suppressor at $50 \mathrm{~mA}$, and eluent flow rate at $0.40 \mathrm{~mL} / \mathrm{min}$, with a $2 \times 250 \mathrm{~mm}$ CS 18 column $(+2 \times 50 \mathrm{~mm}$ AG18 guard column). The eluent concentration was $30 \mathrm{mM}$ for the duration (30 $\mathrm{min}$ ) of the analysis.

The fat content (as fatty acids) of the wastewater was quantified using a Varian ProStar 230 liquid chromatograph (Varian Inc., Palo Alto, CA, USA). A gradient elution using acetonitrile (ACN) and dichloromethane (DCM) was used ( 85 vol. $\%$ ACN initially, then to 30 vol. $\%$ ACN over $30 \mathrm{~min}$ ), with a flowrate of $0.8 \mathrm{~mL} / \mathrm{min}$. The chromatograph was equipped with an Alltech alpha bond C18 125A (5-micron particle size) (Alltech Associates Inc., Deerfield, IL) and was operated at $35^{\circ} \mathrm{C}$. The fatty acids were quantified using an Agilent 6340 mass spectrometer (MS) with an atmospheric pressure chemical ionization (APCI) interface (Agilent, Santa Clara, CA, USA) in the positive ion mode. The MS scanned from 120 to 1100 at $26,000 \mathrm{~m} / \mathrm{z}$ per second. Nitrogen was used as nebulizer gas at $30 \mathrm{psi}$ and heated to $400{ }^{\circ} \mathrm{C}$. The drying gas was held at $300^{\circ} \mathrm{C}$ at a flow rate of $10 \mathrm{~L} / \mathrm{min}$. 


\subsubsection{Analyses of Gaseous and Liquid Digestion Samples}

Collected biogas samples were analyzed using an Agilent $6890 \mathrm{~N}$ gas chromatograph (GC) equipped with a thermal conductivity detector (TCD) (Agilent, Santa Clara, CA, USA). Analyses were conducted with Helium as the carrier gas and using an 80/100 mesh, $6 \mathrm{ft} . \times 2 \mathrm{~mm}$ ID Porapak-Q and 80/100 mesh, $10 \mathrm{ft} . \times 1 / 8$ in. Molesieve 5A columns in series (Restek, Bellefonte, PA, USA). The injector and detector were operated at $150{ }^{\circ} \mathrm{C}$ and $180^{\circ} \mathrm{C}$, respectively. The GC oven was programmed at $70{ }^{\circ} \mathrm{C}$ for $2 \mathrm{~min}$, ramped to $130^{\circ} \mathrm{C}$ at $10^{\circ} \mathrm{C} / \mathrm{min}$, and held at $130{ }^{\circ} \mathrm{C}$ for $2 \mathrm{~min}$.

A HP 1100 liquid chromatograph (LC) equipped with a diode array detector (DAD) (Agilent, Santa Clara, CA, USA) was used for the analysis of the liquid samples. Samples were filtered through 0.45-micron nylon syringe filter prior to analysis. Detection of short chain carboxylic acids was accomplished at $210 \mathrm{~nm}$. The analysis was accomplished using a Rezex ROA-Organic acid column $(300 \times 7.8 \mathrm{~mm})$ equipped with a guard column cartridge system (Phenomenex, Torrance, CA, USA) operated at $40{ }^{\circ} \mathrm{C}$ for $30 \mathrm{~min}$, with $0.6 \mathrm{~mL} / \mathrm{min}$ of $0.005 \mathrm{~N} \mathrm{H}_{2} \mathrm{SO}_{4}$ as the mobile phase.

\section{Results and Discussions}

\subsection{Influent Evaluation and Characteristics}

The characteristics of the catfish processing wastewaters collected from the two locations are presented in Table 2. It can be seen that the wastewaters had a neutral $\mathrm{pH}$ which is optimal for supporting methane production using an anaerobic digester. The COD concentration range of the full-strength wastewater indicates a medium-strength influent that is well within the range of concentrations easily treated using anaerobic digesters $[13,26,27]$. The partially-treated wastewater has approximately $575 \mathrm{mg} \mathrm{COD} / \mathrm{L}$, indicating a fairly low-strength influent for a digester.

Table 2. Characteristics of catfish processing wastewater collected from the two locations indicated in Figure 1.

\begin{tabular}{ccc}
\hline Characteristic & $\begin{array}{c}\text { Full-Strength Wastewater } \\
\text { (Location 1) }\end{array}$ & $\begin{array}{c}\text { Partially-Treated Wastewater } \\
\text { (Location 2) }\end{array}$ \\
\hline $\mathrm{pH}$ & $7-7.3$ & 7.8 \\
COD, mg/L & $2317-5383$ & 575 \\
Fatty acids, mg/L & $2704^{1}$ & $\mathrm{ND}^{2}$ \\
Nitrite-N, mg/L & $1.2-5.2$ & 3.9 \\
Nitrate-N, mg/L & BDL ${ }^{2}$ & 0.8 \\
Ammonia-N, mg/L & $8.5-22.8$ & 17.0 \\
Sulfate, mg/L & BDL-4.1 & 6.3 \\
Phosphate, mg/L & $411.6-430.4$ & 203.5 \\
Sodium, mg/L & $332.6-336.0$ & 317.9 \\
Potassium, mg/L & $107.2-163.7$ & 46.4 \\
Magnesium, mg/L & $7.1-16.1$ & 0.7 \\
Calcium, mg/L & $2.7-6.6$ & 7.3 \\
Chloride, mg/L & $137.4-202.4$ & 185 \\
Flouride, $\mathrm{mg} / \mathrm{L}$ & $\mathrm{BDL}-25.3$ & 0.8 \\
COD:Total N & $83-555$ & 26.5 \\
COD:P & $17-40$ & 9 \\
\hline
\end{tabular}

The catfish processing wastewaters collected from the two different locations were also evaluated for their potential to produce methane without any prior treatment or amendments. The results of this initial evaluation are presented in Figure 4, indicating that the full-strength wastewater had almost negligible methane production potential, while the partially-treated wastewater had the potential to produce $\sim 400 \mathrm{~m}^{3} \mathrm{CH}_{4} /$ ton (U.S.) COD (at $\sim 70$ vol. $\% \mathrm{CH}_{4}$ content) over the 80 -day evaluation period. The chemical characterization of the two wastewaters indicated that the full-strength had at least four 
times higher COD than the partially-treated waste (see Table 2). Although the results suggest that the partially-treated wastewater is the better influent to an anaerobic digestion unit, the low COD content of this stream makes it an undesirable option with respect to volume of $\mathrm{CH}_{4}$ that can be produced per unit volume of wastewater. The results also suggest that something has to be done to the full-strength wastewater for it to be a viable option for anaerobic digestion.

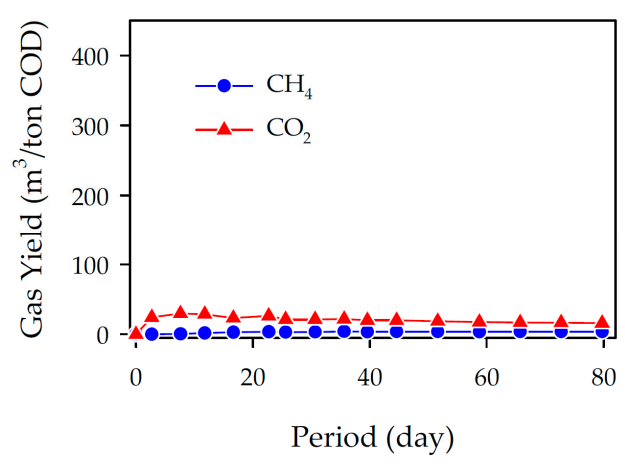

(a)

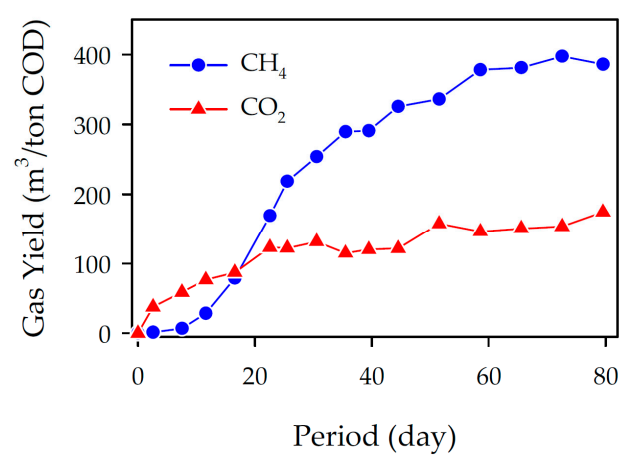

(b)

Figure 4. Initial screening (control) on the potential of catfish processing wastewater for biogas production through anaerobic digestion at $35^{\circ} \mathrm{C}$ : (a) full-strength wastewater (location 1); (b) partially-treated wastewater (location 2).

As shown in Table 2, none of the other wastewater components (i.e., nutrients), except at times the $\mathrm{N}$ and $\mathrm{S}$ levels, were present in concentrations of concern. Due to variability within the catfish processing operations, $\mathrm{N}$ and $\mathrm{S}$ concentrations are sometimes less than ideal for anaerobic digestion and hence were amended with required nutrients. In addition, several pretreatments were evaluated, as described in Section 2.3. The nutrient amendment and pretreatments were applied only to the full-strength wastewater, which is the more viable option as a digester influent with respect to COD load.

\subsection{Nutrient Amendment}

Studies indicate that the mass ratios of COD to $\mathrm{N}$ (COD:N) and COD to P (COD:P) are critical for the anaerobic digestion process. A study of the COD:N ratios within some digester systems that were successfully meeting performance goals were in the 80 to 160 range, according to Poggi-Varaldo et al. [28]. Typically, however, a COD:N of $\sim 40$ is recommended [29]. The level of ammonia, which is the common source of $\mathrm{N}$, needs to be balanced as well since it can inhibit anaerobic digestion processes at concentrations greater than $1000 \mathrm{mg} / \mathrm{L}$ [30,31]. Webb and Hawkes [32] reported that ammonia levels in the $140 \mathrm{mg} / \mathrm{L}$ range were ideal for poultry litter digestion. Hence, for this study, the initial COD: $\mathrm{N}$ ratios were adjusted to 40 by the addition of $\mathrm{NH}_{4} \mathrm{Cl}$. This targeted COD:N ratio kept the total ammonia levels of the amended wastewater within the $70-170 \mathrm{mg} / \mathrm{L}$ range, which is way less than its known inhibitory levels.

Typically, COD:P for anaerobic digestion processes can vary from 80 to 200 [29]. This suggests that the phosphate levels in the full-strength wastewater were higher than recommended. However, Lei et al. [33] found that a phosphate concentration of $465 \mathrm{mg} / \mathrm{L}$ produced a stable and effective digester system for treating rice straw. Wang et al. [34] also came to similar conclusions with their study of phosphate concentration impacts on the digestion of waste activated sludge. Hence, the phosphate concentrations in the wastewater (see Table 2) were considered to be acceptable levels.

The sulfur (S) concentration is equally important in digester operations and has been reported to be between 0.001 and $1 \mathrm{mg} / \mathrm{L}$ [29]. Hence, it was decided that all of the microcosms would be dosed, if needed, with enough $\mathrm{Na}_{2} \mathrm{SO}_{4}$ to yield an initial total sulfur concentration of $0.5 \mathrm{mg} / \mathrm{L}$.

Figure $5 \mathrm{a}$ presents the results of the digestion of full-strength catfish wastewater with nutrient amendment. Up until Day 14, significant biogas production was observed, with very little additional

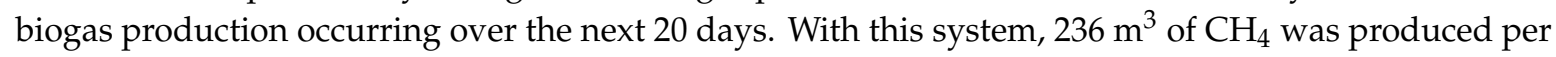


ton (U.S.) of input COD over the 35 days of anaerobic digestion. The methane content of the biogas produced was close to 80 vol. $\% \mathrm{CH}_{4}$ by Day 20 and remained at this level until the completion of the tests. These results indicate that the full-strength catfish processing wastewater was digestible and capable of producing a good quality biogas at a reasonable rate with only $\mathrm{N}$ and $\mathrm{S}$ amendments. Nevertheless, the obtained yield was still much lower than the yield obtained from the partially-treated wastewater ( $\sim 400 \mathrm{~m}^{3} \mathrm{CH}_{4} /$ ton (U.S.) COD). Thus, pretreatment strategies were applied to the nutrient amended full-strength wastewater to further increase the yield of methane from this influent.

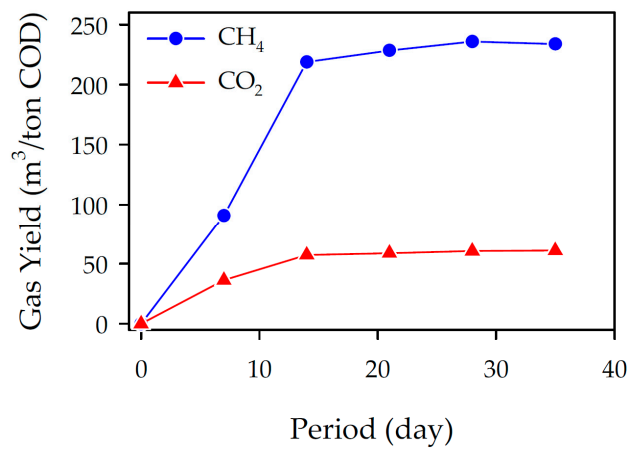

(a)

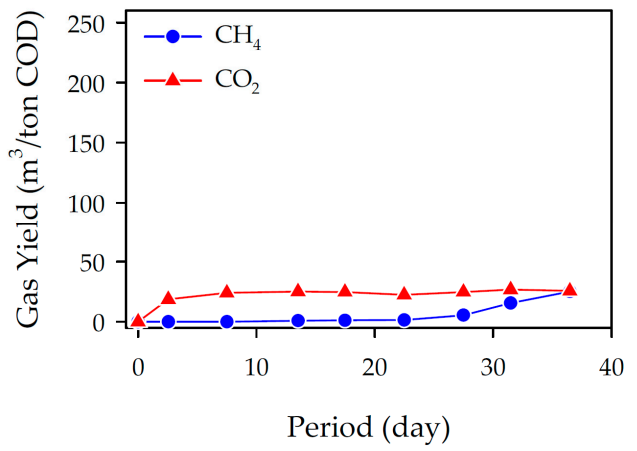

(c)

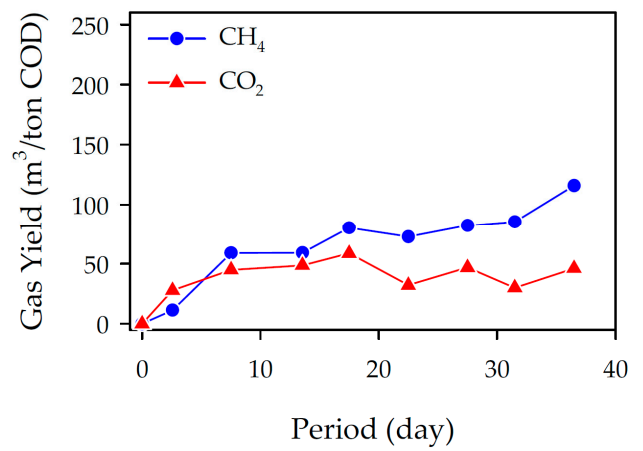

(b)

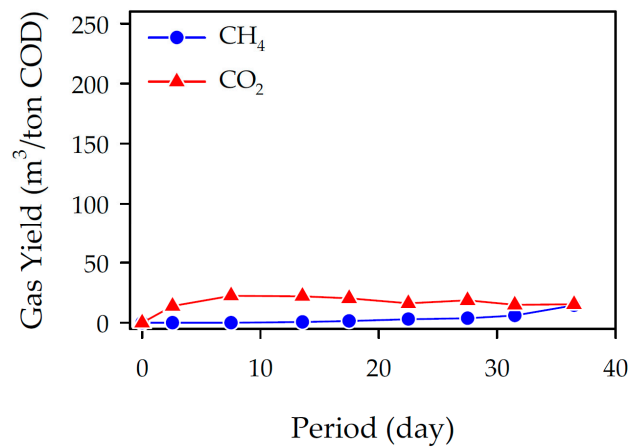

(d)

Figure 5. Evaluation of different strategies to enhance biogas production from the full-strength catfish processing wastewater using anaerobic digestion: (a) nutrient amendment; (b) ozone pretreatment + nutrient amendment; (c) $\mathrm{HCl}$ pretreatment + nutrient amendment; (d) $\mathrm{NaOH}$ pretreatment + nutrient amendment.

\subsection{Pretreatment of Full-Strength Catfish Processing Wastewater}

The following three pretreatments with reported successes with enhancing anaerobic digestion systems were evaluated: ozone pretreatment, $\mathrm{HCl}$ pretreatment, and $\mathrm{NaOH}$ pretreatment [35]. Ozone pretreatment or ozonation was evaluated with the thought that partial oxidation of the organics would render the wastewater more amenable to biodegradation, as reported by several researchers [36-38]. Acid pretreatment was considered as a potential means of destabilizing complex proteins and lipids (breaks down into free fatty acids, which are easier to degrade). Devlin et al. [39] found that $\mathrm{HCl}$ pretreatment to a $\mathrm{pH}$ of 2 enhanced the biogas production of waste activated sludge. Lastly, $\mathrm{NaOH}$ pretreatment was evaluated with the hopes that the conversion of free fatty acids to saponified compounds and degradation of proteins into more soluble products would improve the methane yield of the full-strength wastewater, as reported by previous studies [40-42].

Figure $5 b-d$ presents the results of the anaerobic digestion of pretreated full-strength catfish wastewater. Results show that the ozone pretreatment exhibited a significantly higher methane yield compared to $\mathrm{HCl}$ and $\mathrm{NaOH}$ pretreatment. In fact, methane production was fairly constant for ozone pretreated wastewater over the 36 days of incubation, as opposed to methane production lag phases observed during the beginning of the incubations with the other pretreatments. At Day 36, the ozone 
pretreated system yielded $\sim 116 \mathrm{~m}^{3} /$ ton (U.S.) $\mathrm{COD}_{\text {input }}$ versus only $\sim 25$ and $\sim 15$ for the $\mathrm{HCl}$ and $\mathrm{NaOH}$ pretreated systems, respectively.

For all the digestion runs presented in Figure 5, the rates of methane production were calculated using the cubic spline differentiation function of MathCad 15.0 and the results are presented in Figure 6 . For the first 20 days of incubation, the rates of methane production were highest for the nutrient amended system, followed by the ozone pretreated wastewater, and were almost negligible for both the $\mathrm{HCl}$ and $\mathrm{NaOH}$ pretreated wastewater. After 20 days, the rate of methane production significantly decreased for both the amended and ozone pretreated systems. In contrast, a significant increase in methane production rates was observed for both the $\mathrm{HCl}$ and $\mathrm{NaOH}$ pretreated wastewater. Thus, the $\mathrm{HCl}$ and $\mathrm{NaOH}$ pretreated systems were incubated for an extended period of about 80 days (similar to the unmodified wastewaters shown in Figure 4) to determine if the systems would recover for the initial lag and yield methane, similar to the partially-treated wastewater. The results of extended incubation are presented in Figure 7, which shows that both systems did recover from the initial lag in methane production. The $\mathrm{HCl}$ pretreated system ended up having a higher methane yield $\left(192 \mathrm{~m}^{3}\right.$ $\mathrm{CH}_{4} /$ ton (U.S.) $\mathrm{COD}_{\text {input }}$ ), which is also the only pretreatment that resulted in yield close to the nutrient amended system $\left(236 \mathrm{~m}^{3} \mathrm{CH}_{4} /\right.$ ton (U.S.) $\left.\mathrm{COD}_{\text {input }}\right)$.

Ozone treatment $\left(300 \mathrm{mg} \mathrm{O}_{3} / \mathrm{L}\right.$ ) is known to reduce or oxidize the fats, oils, and greases of wastewater, which could mean losses of wastewater COD [43]. It is for this reason that the ozone dosage applied to the wastewater was similar to water disinfection levels ( $3-13 \mathrm{mg} \mathrm{O}_{3} / \mathrm{L}$ ) [44,45]. Since the membrane of microbes is made up of fats (or lipids), this low level of ozone ensures that the fats content of the full-strength wastewater (see Table 2) is affected (partially-oxidized) by ozone treatment. Based on the results, the ozonation could still have reduced the COD of the full-strength wastewater significantly, resulting in a lower methane yield compared to the nutrient amended system. This COD reduction was not accounted for in the present study, since the yield comparison has to be based on the COD input of the overall process (pretreatment + anaerobic digestion) and not based on anaerobic digestion by itself.

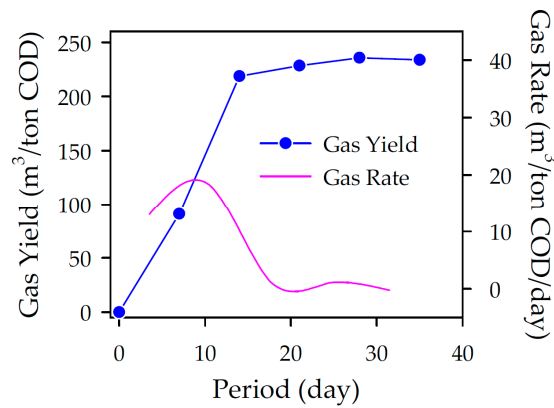

(a)

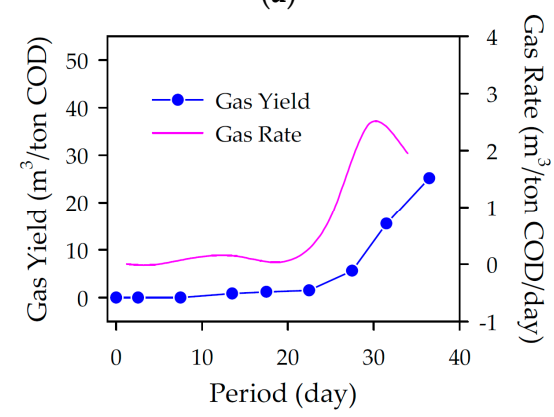

(c)

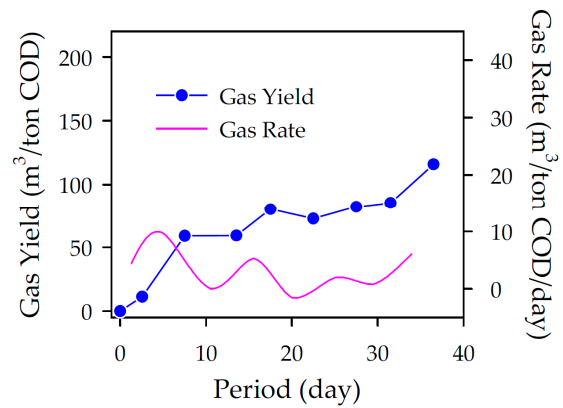

(b)

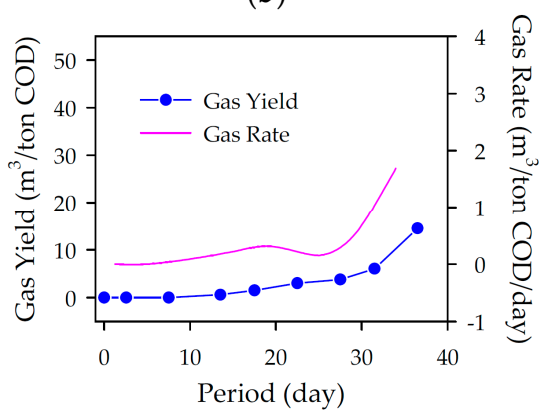

(d)

Figure 6. Methane yield and production rate within the first 40 days of digestion of full-strength catfish processing wastewater: (a) nutrient amendment; (b) ozone pretreatment + nutrient amendment; (c) $\mathrm{HCl}$ pretreatment + nutrient amendment; (d) $\mathrm{NaOH}$ pretreatment + nutrient amendment. 


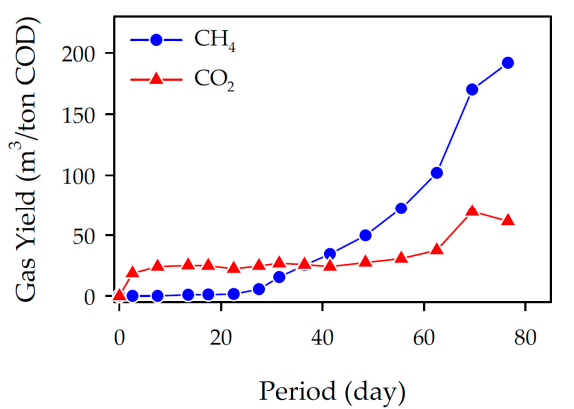

(a)

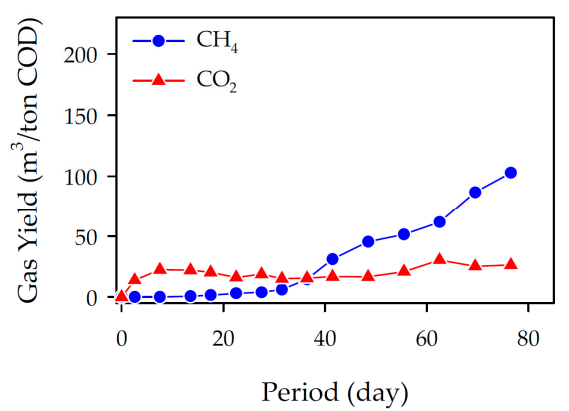

(b)

Figure 7. Extended period of digestion of the full-strength catfish processing wastewater: (a) $\mathrm{HCl}$ pretreatment + nutrient amendment; (b) $\mathrm{NaOH}$ pretreatment + nutrient amendment.

The $\mathrm{HCl}$ and $\mathrm{NaOH}$ pretreatments exhibited similar methane yield profiles, as shown in Figure 7. For both systems, the digestion characteristic could be due to the behavior of fats when subjected to different $\mathrm{pH}$ conditions. Although the form or speciation of the fats in the unmodified full-strength wastewater was not determined, it was apparent that they were amenable to anaerobic digestion (as short as 14 days) with nutrient amendment. Lowering the $\mathrm{pH}$ of the wastewater could have resulted in the conversion of the fats into fatty acids, which are inhibitory to anaerobic digestion, particularly the microorganisms that are responsible for methane production (methanogens). In a study conducted by Cirne et al. [46], they found that anaerobic digestion of triolein (a fat composed of oleic acid) could take longer than 80 days due to fatty acid inhibition. It was anticipated that the $\mathrm{NaOH}$ pretreatment would result in better solubilization of the fats through saponification, and thus a shorter incubation requirement or a higher methane yield would be observed. However, the results suggested otherwise, indicating that the saponification seemed to hinder the amenability of the fats to anaerobic digestion compared to the nutrient amended system. This resulted in the delay or lag during the digestion, as was observed by Salah [47], on the digestion of saponified long chain fatty acids, where a significant rate of methane production was obtained only after 40 days of incubation. It is noteworthy to mention that the $\mathrm{pH}$ of all the resulting feedstock after amendment and pretreatment was adjusted to neutral prior to digestion to eliminate any $\mathrm{pH}$ effects on the digestion performance.

\subsection{Semi-Batch Digestion Runs}

Among the strategies tested, it was apparent from the results that the recalcitrance of the full-strength catfish wastewater to anaerobic digestion was primarily due to nutrient (N and $\mathrm{S}$ ) deficiency. Furthermore, none of the pretreatments tested was able to improve the methane yield of the wastewater compared to the nutrient amendment. Thus, to better mimic actual field operations, semi-batch (15 L) digestion runs were performed on the nutrient amended system.

Figures 8-10 present the results of these runs, indicating an almost similar behavior as the $500-\mathrm{mL}$ microcosms. After 14 days of incubation, the anaerobic digestion ceased and produced a biogas that contained $70 \mathrm{vol} \% \%$ methane. However, the yield of methane was lower $\left(121-127 \mathrm{~m}^{3} / \mathrm{COD}_{\text {input }}\right)$ compared to the $500-\mathrm{mL}$ microcosms $\left(236 \mathrm{~m}^{3} / \mathrm{COD}_{\text {input }}\right)$. This could be due to the instantaneous release of biogas in the 15-L reactors, which translates to lower $\mathrm{CO}_{2}$ and $\mathrm{H}_{2}$ retention in the system. Methane production during anaerobic digestion is a combination of the acetotrophic and hydrogenotrophic pathways, as shown below [48].

$$
\begin{aligned}
& \text { Acetotrophic: } \mathrm{CH}_{3} \mathrm{COO}^{-}+\mathrm{H}^{+} \rightarrow \mathrm{CH}_{4}+\mathrm{CO}_{2} \text {, } \\
& \text { Hydrogenotrophic: } 4 \mathrm{H}_{2}+\mathrm{CO}_{2} \rightarrow \mathrm{CH}_{4}+2 \mathrm{H}_{2} \mathrm{O} \text {. }
\end{aligned}
$$

The acetotrophic pathway represents the degradation of acetic acid (produced from longer chain organic acid such as butyric acid) into methane and carbon dioxide, while the hydrogenotrophic 
pathway refers to the consumption of hydrogen and carbon dioxide (produced from the preceding reaction steps) to produce methane and water. The longer biogas retention time of the microcosm set-up allowed Reaction 2 to have significant contribution to the process. This is supported by the undetected concentration of hydrogen in the microcosm runs, while significant hydrogen was detected in the semi-batch runs. Furthermore, the higher concentration of methane in the microcosm runs ( 80 vol.\%) compared to the semi-batch runs (70 vol.\%) suggests that Reaction 2 was less active in the latter. Taconi et al. [12] also reported that the hydrogenotrophic pathway is a significant methane production mechanism for acetic acid digestion. The results also showed that butyric acid was the predominant organic acid produced during the digestion process (Figure 10), which was then consumed to produce acetic acid and, subsequently, biogas. Thus, negligible concentrations of organic acids were detected at the end of the 16-day incubation.

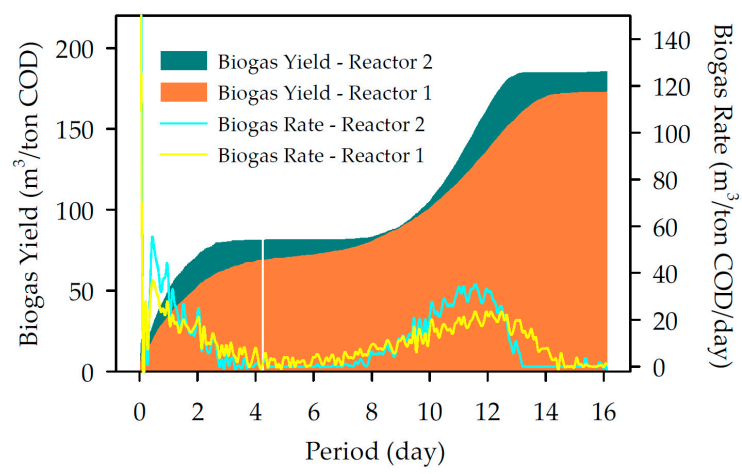

Figure 8. Biogas production during the semi-batch anaerobic digestion of nutrient amended catfish processing wastewater.

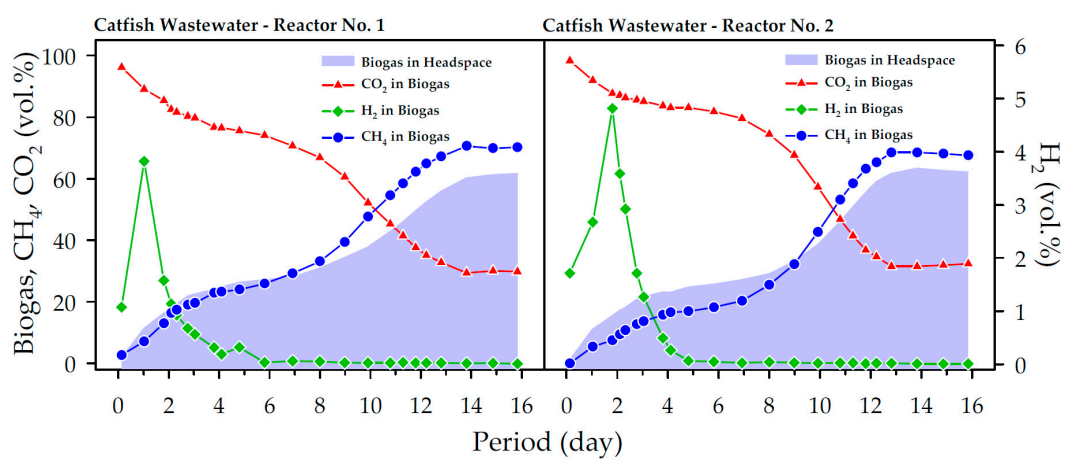

Figure 9. Composition of biogas produced during the semi-batch anaerobic digestion of nutrient amended catfish processing wastewater.

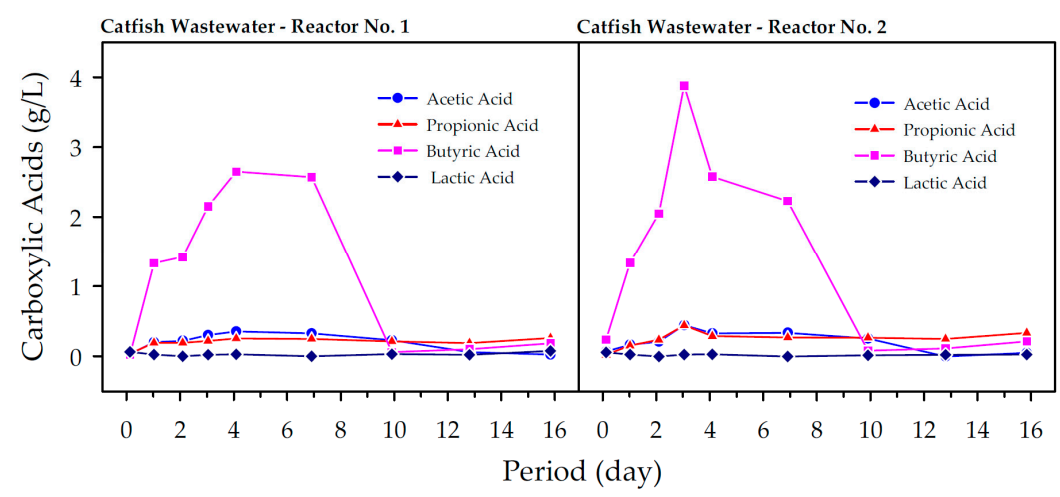

Figure 10. Organic acid production during the semi-batch anaerobic digestion of nutrient amended catfish processing wastewater. 


\subsection{Implications of Results}

The results of this work indicate that anaerobic digestion could possibly replace the first stage of the currently in-place aerobic biotreatment (see Figure 1) to treat the full-strength wastewater of the catfish processor. The replacement would also produce an energetic co-product in the form of methane, which could financially benefit the catfish processor. Table 3 shows that the anaerobic digestion of the nutrient amended full-strength catfish processing wastewater resulted in a methane yield and composition that were similar to common feedstock. However, the first stage COD reduction rates for their existing treatment system is in the $75-90 \%$ range, while the anaerobic digestion of the amended full-strength wastewater was in the $60-65 \%$ range. To better justify the replacement, further optimization study (and subsequent economic evaluation) is needed to further increase the methane yield, as well as improve the COD reduction of the anaerobic digestion process.

Table 3. Methane yield and methane content of some common substrate for mesophilic $\left(30-37.4{ }^{\circ} \mathrm{C}\right)$ anaerobic digestion.

\begin{tabular}{|c|c|c|c|}
\hline Substrate & $\begin{array}{l}\text { Methane Yield }\left(\mathrm{m}^{3} / \text { ton }\right. \\
\text { (U.S.) COD } \text { input })\end{array}$ & $\begin{array}{l}\text { Methane Content } \\
\text { (vol.\%) }\end{array}$ & Reference \\
\hline Food Waste ${ }^{1}$ & $92-330$ & $59-67$ & Gray et al. [49] \\
\hline Food Waste & $231^{2}$ & $\mathrm{ND}^{3}$ & Kubaská et al. [50] \\
\hline Food Waste & $303-397$ & 59 & Grimberg et al. [51] \\
\hline Municipal Wastewater Solids & 236 & 63 & Gray et al. [49] \\
\hline Simulant Human Excreta & 218-399 & $59-64$ & Colón et al. [52] \\
\hline Fish Canning Wastewater & $195-340$ & $63-75$ & Mendez et al. [23] \\
\hline Fish Canning Wastewater & 199-246 & 67 & Balslev-Olesen et al. [21] \\
\hline Fish Canning Wastewater & $680-1179^{2}$ & ND & Prasertsan et al. [53] \\
\hline Catfish Processing Wastewater & $121-236$ & $67-80$ & This Study \\
\hline
\end{tabular}

\section{Conclusions}

Anaerobic digestion, which is a proven waste treatment method that produces methane, was evaluated for its potential as an alternative to aerobic biotreatment of catfish processing wastewater. Initial assessments of the full-strength wastewater indicated that its nitrogen and sulfur contents were below the level recommended for anaerobic digestion. A negligible methane yield ( $4 \mathrm{~m}^{3} /$ ton (U.S.) $\mathrm{COD}_{\text {input }}$ ) was obtained from the unmodified (initial $\mathrm{pH}$-adjusted) full-strength wastewater. Among the strategies tested (nutrient amendment and pretreatment: ozone, $\mathrm{HCl}$, and $\mathrm{NaOH}$ ), results showed that nutrient (nitrogen and sulfur) amendment alone could improve the digestibility of the catfish processing wastewater. A methane yield of $121-236 \mathrm{~m}^{3} /$ ton (U.S.) $\mathrm{COD}_{\text {input }}$ was obtained with a purity of $67-80 \mathrm{vol} . \%$, which are similar to yields and purities of biogas obtained from other feedstock. These results suggest the viability of anaerobic digestion as an option for treatment and energetic co-product production from catfish processing wastewater. Further optimization study for accurate estimation of system economics is needed to make a sound engineering decision.

Author Contributions: Conceptualization, M.E.Z., R.B., D.G., R.H. and E.D.R.; Methodology and Investigation, D.L.F., W.S., W.H. and E.D.R.; Resources and Validation, D.L.F., W.H. and E.D.R.; Data Curation, D.L.F. and E.D.R.; Writing-Original Draft Preparation, M.E.Z.; Writing-Review \& Editing, D.L.F., W.S., R.B., D.G., R.H., and E.D.R.; Funding Acquisition, M.E.Z. All authors discussed the results and contributed to the final version of the manuscript.

Funding: This research was funded by Cleco Power, LLC (Pineville, LA, USA) and the Energy Institute of Louisiana (EIL) at the University of Louisiana.

Acknowledgments: The able assistance of the many students and staff of the EIL are acknowledged and appreciated. Finally, deep appreciation is felt toward the Louisiana Public Service Commission for their support of this study and efforts that encourage the development of economically viable alternative energy options for Louisiana.

Conflicts of Interest: The authors declare no conflict of interest. 


\section{References}

1. Upton, H.F. U.S. Catfish Industry and Foreign Trade: A Fact Sheet; Congressional Research Service: Washington, DC, USA, 2015.

2. Hanson, T.; Sites, D. 2014 U.S. Catfish Database; Auburn University, Mississipi State University: Auburn, AL, USA, 2015.

3. Lopes, C.; Antelo, L.T.; Franco-Uría, A.; Alonso, A.A.; Pérez-Martín, R. Valorisation of Fish by-Products against Waste Management Treatments-Comparison of Environmental Impacts. Waste Manag. 2015, 46, 103-112. [CrossRef] [PubMed]

4. Yeo, S.E.; Binkowski, F.P.; Morris, J.E. Aquaculture Effluents and Waste by-Products Characteristics, Potential Recovery, and Beneficial Reuse; North Central Regional Aquaculture Center: Ames, IA, USA, 2004.

5. Lovell, R.T. Utilization of Catfish Processing Waste; Auburn University, Agriculture Experiment Station: Auburn, AL, USA, 1980.

6. Silva, J.L.; Dean, S. Processed Catfish Product Forms, Packaging, Yields and Product Mix; Southern Regional Aquaculture Center: Mississippi State, MS, USA, 2001.

7. Jayathilakan, K.; Sultana, K.; Radhakrishna, K.; Bawa, A.S. Utilization of Byproducts and Waste Materials from Meat, Poultry and Fish Processing Industries: A Review. J. Food Sci. Technol. 2012, 49, 278-293. [CrossRef] [PubMed]

8. Sahu, B.; Barik, N.; Agnibesh, A.; Paikaray, A.; Mohapatra, S.; Senapati, S.; Das, K.; Sundaray, J. Recycled Fish Processing Waste for Welfare of Aquaculture Industry: A Review. Int. J. Fish. Aquat. Res. 2017, 2, 37-42.

9. Afonso, M.D.; Bórquez, R. Review of the Treatment of Seafood Processing Wastewaters and Recovery of Proteins Therein by Membrane Separation Processes-Prospects of the Ultrafiltration of Wastewaters from the Fish Meal Industry. Desalination 2002, 142, 29-45. [CrossRef]

10. Chowdhury, P.; Viraraghavan, T.; Srinivasan, A. Biological Treatment Processes for Fish Processing Wastewater-A Review. Bioresour. Technol. 2010, 101, 439-449. [CrossRef] [PubMed]

11. Veiga, M.C.; Méndez, R.; Lema, J.M. Anaerobic Filter and DSFF Reactors in Anaerobic Treatment of Tuna Processing Wastewater. Water Sci. Technol. 1994, 30, 425-432. [CrossRef]

12. Taconi, K.A.; Zappi, M.E.; Todd French, W.; Brown, L.R. Methanogenesis under Acidic pH Conditions in a Semi-Continuous Reactor System. Bioresour. Technol. 2008, 99, 8075-8081. [CrossRef] [PubMed]

13. Speece, R.E. Anaerobic Biotechnology for Industrial Wastewater Treatment. Environ. Sci. Technol. 1983, 17, 416A-427A. [CrossRef] [PubMed]

14. Herout, M.; Malat'ák, J.; Kučera, L.; Dlabaja, T. Biogas Composition Depending on the Type of Plant Biomass Used. Res. Agric. Eng. 2011, 57, 137-143. [CrossRef]

15. Carroad, P.A.; Wilke, C.R. Enzymes and Microorganisms in Food Industry Waste Processing and Conversion to Useful Products: A Review of the Literature. Resour. Recovery Conserv. 1978, 3, 165-178. [CrossRef]

16. Beddoes, J.C.; Bracmort, K.S.; Burns, R.T.; Lazarus, W.F. An Analysis of Energy Production Costs from Anaerobic Digestion Systems on U.S. Livestock Production Facilities; United States Department of Agriculture: Washington, DC, USA, 2007.

17. Ernst, M.; Rodecker, J.; Luvaga, E.; Alexander, T.; Kliebenstein, J.; Miranowski, J. Viability of Methane Production by Anaerobic Digestion on Iowa Swine Farms; Departmet of Economics, Iowa State University: Ames, IA, USA, 1999.

18. Lund, S.C. An Analysis of the Feasibility of Anaerobic Digestion on Small-Scale Dairies in Utah; MS International Food and Agribusiness, Utah State University: Logan, UT, USA, 2016.

19. Roos, K.F.; Martin, J.B., Jr.; Moser, M.A. A Manual for Developing Biogas Systems at Commercial Farms in the United States: Agstar Handbook; US Environmental Protection Agency: Washington DC, USA, 2004.

20. Ronde, H.; Ranne, A.; Pursiheimo, E. Integrated Renewable Energy Solutions for Seafood Processing Stations. In Proceedings of the International Conference on Energy and Sustainable Development: Issues and Strategies (ESD 2010), Chiang Mai, Thailand, 2-4 June 2010; pp. 1-7.

21. Balslev-Olesen, P.; Lynggaard-Jensen, A.; Nickelsen, C. Pilot-Scale Experiments on Anaerobic Treatment of Wastewater from a Fish Processing Plant. Water Sci. Technol. 1990, 22, 463-474. [CrossRef]

22. Kafle, G.K.; Kim, S.H. Evaluation of the Biogas Productivity Potential of Fish Waste: A Lab Scale Batch Study. J. Biosyst. Eng. 2012, 37, 302-313. [CrossRef] 
23. Mendez, R.; Lema, J.M.; Soto, M. Treatment of Seafood-Processing Wastewaters in Mesophilic and Thermophilic Anaerobic Filters. Water Environ. Res. 1995, 67, 33-45. [CrossRef]

24. Gumisiriza, R.; Mshandete, A.; Rubindamayugi, M.; Kansiime, F.; Kivaisi, A. Enhancement of Anaerobic Digestion of Nile Perch Fish Processing Wastewater. Afr. J. Biotechnol. 2009, 8, 328-333.

25. Palenzuela-Rollon, A.; Zeeman, G.; Lubberding, H.J.; Lettinga, G.; Alaerts, G.J. Treatment of Fish Processing Wastewater in a One- or Two-Step Upflow Anaerobic Sludge Blanket (Uasb) Reactor. Water Sci. Technol. 2002, 45, 207-212. [CrossRef] [PubMed]

26. Ali, A.H.; Jasem, N.A.; Attia, H.G. The Use of Anaerobic Digestion Process in the Treatment of Dairy Wastewater by Microorganisms Derived from Sewage Wasted Sludge. J. Eng. Dev. 2012, 16, 181-194.

27. Chen, Y.; Cheng, J.J.; Creamer, K.S. Inhibition of Anaerobic Digestion Process: A Review. Bioresour. Technol. 2008, 99, 4044-4064. [CrossRef] [PubMed]

28. Poggi-Varaldo, H.M.; Rodríguez-Vázquez, R.; Fernández-Villagómez, G.; Esparza-García, F. Inhibition of Mesophilic Solid-Substrate Anaerobic Digestion by Ammonia Nitrogen. Appl. Microbiol. Biotechnol. 1997, 47, 284-291. [CrossRef]

29. Anderson, K.; Sallis, P.; Uyanik, S. Anaerobic Treatment Processes. In The Handbook of Water and Wastewater Microbiology; Mara, D.D., Horan, N.J., Eds.; Academic Press: New York, NY, USA, 2003; pp. 391-426.

30. Bhattacharya, S.K.; Parkin, G.F. The Effect of Ammonia on Methane Fermentation Processes. Water Pollut. Control Fed. 1989, 61, 55-59.

31. Moestedt, J.; Müller, B.; Westerholm, M.; Schnürer, A. Ammonia Threshold for Inhibition of Anaerobic Digestion of Thin Stillage and the Importance of Organic Loading Rate. Microb. Biotechnol. 2016, 9, 180-194. [CrossRef]

32. Webb, A.R.; Hawkes, F.R. The Anaerobic Digestion of Poultry Manure: Variation of Gas Yield with Influent Concentration and Ammonium-Nitrogen Levels. Agric. Wastes 1985, 14, 135-156. [CrossRef]

33. Lei, Z.; Chen, J.; Zhang, Z.; Sugiura, N. Methane Production from Rice Straw with Acclimated Anaerobic Sludge: Effect of Phosphate Supplementation. Bioresour. Technol. 2010, 101, 4343-4348. [CrossRef] [PubMed]

34. Wang, R.; Vanrolleghem, P.A.; Li, Y.; Wang, W. Effect of High Orthophosphate Concentrations on Methane Production During Mesophilic Anaerobic Digestion. In Proceedings of the NRR2013, Vancouver, BC, Canada, 29-31 July 2013.

35. Zhen, G.; Lu, X.; Kato, H.; Zhao, Y.; Li, Y.-Y. Overview of Pretreatment Strategies for Enhancing Sewage Sludge Disintegration and Subsequent Anaerobic Digestion: Current Advances, Full-Scale Application and Future Perspectives. Renew. Sustain. Energy Rev. 2017, 69, 559-577. [CrossRef]

36. Bougrier, C.; Battimelli, A.; Delgenes, J.-P.; Carrere, H. Combined Ozone Pretreatment and Anaerobic Digestion for the Reduction of Biological Sludge Production in Wastewater Treatment. Ozone Sci. Eng. 2007, 29, 201-206. [CrossRef]

37. Goel, R.; Tokutomi, T.; Yasui, H. Anaerobic Digestion of Excess Activated Sludge with Ozone Pretreatment. Water Sci. Technol. 2003, 47, 207-214. [CrossRef] [PubMed]

38. Carballa, M.; Manterola, G.; Larrea, L.; Ternes, T.; Omil, F.; Lema, J.M. Influence of Ozone Pre-Treatment on Sludge Anaerobic Digestion: Removal of Pharmaceutical and Personal Care Products. Chemosphere 2007, 67, 1444-1452. [CrossRef] [PubMed]

39. Devlin, D.C.; Esteves, S.R.R.; Dinsdale, R.M.; Guwy, A.J. The Effect of Acid Pretreatment on the Anaerobic Digestion and Dewatering of Waste Activated Sludge. Bioresour. Technol. 2011, 102, 4076-4082. [CrossRef]

40. Battimelli, A.; Torrijos, M.; Moletta, R.; Delgenès, J.P. Slaughterhouse Fatty Waste Saponification to Increase Biogas Yield. Bioresour. Technol. 2010, 101, 3388-3393. [CrossRef]

41. Mouneimne, A.H.; Carrère, H.; Bernet, N.; Delgenès, J.P. Effect of Saponification on the Anaerobic Digestion of Solid Fatty Residues. Bioresour. Technol. 2003, 90, 89-94. [CrossRef]

42. Battimelli, A.; Carrère, H.; Delgenès, J.-P. Saponification of Fatty Slaughterhouse Wastes for Enhancing Anaerobic Biodegradability. Bioresour. Technol. 2009, 100, 3695-3700. [CrossRef]

43. Robertson, L.; Britz, T.J.; Sigge, G.O. Impact of Ozone Pre-Treatment on the Performance of Upflow Anaerobic Sludge Blanket Treating Pre-Treated Grain Distillery Wastewater. Water Sci. Technol. 2014, 70, 1702-1708. [CrossRef] [PubMed]

44. Martínez, S.B.; Pérez-Parra, J.; Suay, R. Use of Ozone in Wastewater Treatment to Produce Water Suitable for Irrigation. Water Resour. Manag. 2011, 25, 2109-2124. [CrossRef] 
45. Oneby, M.A.; Bromley, C.O.; Borchardt, J.H.; Harrison, D.S. Ozone Treatment of Secondary Effluent at U.S. Municipal Wastewater Treatment Plants. Ozone Sci. Eng. 2010, 32, 43-55. [CrossRef]

46. Cirne, D.G.; Paloumet, X.; Björnsson, L.; Alves, M.M.; Mattiasson, B. Anaerobic Digestion of Lipid-Rich Waste-Effects of Lipid Concentration. Renew. Energy 2007, 32, 965-975. [CrossRef]

47. Salah, R.A. Study of Methods for the Improvement of the Anaerobic Digestion of Lipids and Long Chain Fatty Acids; Program on Environmental Engineering, Universitat Politècnica de Catalunya: Barcelona, Spain, 2013.

48. Rapport, J.; Zhang, R.; Jenkins, B.M.; Williams, R.B. Current Anaerobic Digestion Technologies Used for Treatment of Municipal Organic Solid Waste; California Integrated Waste Management Board, University of California, Davis: Davis, CA, USA, 2008.

49. Gray, D.M.D.; Suto, P.; Peck, C. Anaerobic Digestion of Food Waste; U.S. Environmental Protection Agency Region 9: Washington DC, USA, 2008.

50. Kubaská, M.; Sedláček, S.; Bodík, I.; Kissová, B. Food Waste as Biodegradable Substrates for Biogas Production. In Proceedings of the 37th International Conference of Slovak Society of Chemical Engineering, Tatranské Matliare, Slovakia, 24-28 May 2010; pp. 1413-1418.

51. Grimberg, S.J.; Hilderbrandt, D.; Kinnunen, M.; Rogers, S. Anaerobic Digestion of Food Waste through the Operation of a Mesophilic Two-Phase Pilot Scale Digester-Assessment of Variable Loadings on System Performance. Bioresour. Technol. 2015, 178, 226-229. [CrossRef] [PubMed]

52. Colón, J.; Forbis-Stokes, A.A.; Deshusses, M.A. Anaerobic Digestion of Undiluted Simulant Human Excreta for Sanitation and Energy Recovery in Less-Developed Countries. Energy Sustain. Dev. 2015, 29, 57-64. [CrossRef]

53. Prasertsan, P.; Jung, S.; Buckle, K.A. Anaerobic Filter Treatment of Fishery Wastewater. World J. Microbiol. Biotechnol. 1994, 10, 11-13. [CrossRef] [PubMed]

(C) 2019 by the authors. Licensee MDPI, Basel, Switzerland. This article is an open access article distributed under the terms and conditions of the Creative Commons Attribution (CC BY) license (http://creativecommons.org/licenses/by/4.0/). 